\title{
Costs of reusable and disposable aprons in a public teaching hospital
}

\author{
CUSTOS DE AVENTAIS DE TECIDO REUTILIZÁVEIS E DE DESCARTÁVEIS EM \\ HOSPITAL UNIVERSITÁRIO PÚBLICO
}

\section{COSTOS DE DELANTALES DE TEJIDO REUTILIZABLES Y DE DESECHABLES EN HOSPITAL UNIVERSITARIO PÚBLICO}

\section{Paloma de Souza Cavalcante Pissinati ${ }^{1}$, Maria do Carmo Lourenço Haddad², Mariana Ângela Rossaneis $^{3}$, Roseli Broggi Gil ${ }^{4}$, Renata Aparecida Belei ${ }^{5}$}

\begin{abstract}
Objective: To analyze the direct cost of reusable and disposable aprons in a public teaching hospital. Method: Crosssectional study of quantitative approach, focusing on the direct cost of reusable and disposable aprons at a teaching hospital in northern Paraná. The study population consisted of secondary data collected in reports of the cost of services, laundry, materials and supplies division of the institution for the year 2012. Results: We identified a lower average cost of using disposable apron when compared to the reusable apron. The direct cost of reusable apron was $\mathrm{R} \$ 3.06$, and the steps of preparation and washing were mainly responsible for the high cost, and disposable apron cost was R\$ 0.94. Conclusion: The results presented are important for hospital managers properly allocate resources and manage costs in hospitals
\end{abstract}

\section{RESUMO}

Objetivo: Analisar o custo direto de aventais de tecido reutilizáveis e de descartáveis em hospital universitário público. Método: Estudo transversal de abordagem quantitativa, com enfoque no custo direto de aventais de tecido reutilizáveis e de descartáveis, realizado em hospital universitário do norte do Paraná. A população de estudo foi composta por dados secundários coletados em relatórios dos serviços de custo, lavanderia, divisão de material e suprimentos da instituição, referentes ao ano de 2012. Resultados: Identificou-se um menor custo médio de utilização do avental descartável quando comparado ao do avental de tecido reutilizável. $O$ custo direto de utilização do avental de tecido foi de $R \$ 3,06$, sendo as etapas de confecção e lavagem as principais responsáveis pela elevação do custo, e o avental descartável custou R\$ 0,94. Conclusão: Os resultados apresentados constituem ferramentas para que os gestores hospitalares possam alocar adequadamente os recursos e gerenciar custos em instituições hospitalares.

\section{DESCRITORES \\ Custos hospitalares \\ Enfermagem \\ Gestão em saúde}

\section{RESUMEN}

Objetivo: Analizar el costo directo de delantales de tejido reutilizables y de desechables en hospital universitario público. Método: Estudio transversal de abordaje cuantitativo, con énfasis en el costo directo de los delantales de tejido reutilizables y desechables, realizado en hospital universitario del norte de Paraná. La población de estudio estuvo compuesta de datos secundarios recogidos en informes de los servicios de costo, lavandería, división de material y provisiones de la institución, referentes al año de 2012. Resultados: Se identificó un menor costo medio de utilización del delantal desechable cuando comparado con el costo del delantal de tejido reutilizable. El costo directo de utilización del delantal de tejido fue de $R \$ 3,06$, siendo las etapas de confección y lavado las principales responsables de la elevación del costo, y el delantal desechable costó $\mathrm{R} \$ 0,94$. Conclusión: Los resultados presentados constituyen herramientas para que los gestores hospitalarios puedan destinar adecuadamente los recursos y gestionar los costos en instituciones hospitalarias.

\section{DESCRIPTORES \\ Costos de hospital \\ Enfermería \\ Gestión en salud} ${ }^{1}$ Masters' student in Nursing, Nursing Graduate Program, State University of Londrina, Londrina, PR, Brazil. ${ }^{2}$ PhD, Nursing Department, State University of
Londrina, Londrina, PR, Brazil. ${ }^{3} \mathrm{PhD}$ student in Nursing, Nursing Graduate Program, State University of Maringá, Maringá, PR, Brazil. ${ }^{4}$ Nurse, Office of
Nursing in Control of Material Resources, Teaching Hospital of Londrina, Londrina, PR, Brazil. ${ }^{5}$ Nurse, Committee of the Hospital Infection Control, Teaching
Hospital of Londrina, Londrina, PR, Brazil. 


\section{INTRODUCTION}

In recent years, technological advances in health care, particularly in nursing, contributed to the increased workload and increased susceptibility of workers to occupational hazards such as chemical, physical, ergonomic, biological and accidents, which constitute factors concerning managers of hospital services ${ }^{(1)}$. Therefore, in order to minimize occupational hazards, hospitals provide Personal Protective Equipment (PPE) for workers ${ }^{(2)}$, which aims to protect the individual from threats to their health and safety in the workplace ${ }^{(3)}$.

The provision of PPE became mandatory in institutions by Regulatory Standard No.6, which was updated by Ordinance of the Secretary of the Labour Inspection Board and the Department of Safety and Health at Work in 2010(4). According to this regulatory standard, the employer is responsible to provide appropriate equipment to each activity and the worker must meet the guidelines for the correct use.

In the hospital setting, due to the developed of assistential activities, the most representative PPE are masks and goggles, being used to protect the face, gloves, upper limb, and aprons that are designed to protect the torso of the worker ${ }^{(4)}$. Among the PPE, apron is highlighted due to the increase of its use as a protective barrier during contact with patients colonized by multi-resistant microorganisms (MR).

Microbial resistance has increased considerably in recent years and has become a public health problem worldwide. Additionally, the increased morbidity and mortality of patients and the rising costs of care reinforce the concern of hospital managers with the spread of these microorganisms ${ }^{(5)}$. Therefore, the use of long sleeved aprons during direct contact of professionals with infected or colonized patients by MR is mandatory and essential. This practice aims to reduce contamination of the health worker during the care ${ }^{(3)}$.

The literature suggests two main types of aprons for the protection of health professionals: the reusable apron, which is subjected to washing in laundry after use, and disposable apron, made from material called nonwoven, also classified as ready to use. Choosing for one of these equipment should consider aspects related to asepsis, efficacy as a protective barrier, cost/benefit relationship and environmental sustainability ${ }^{(6)}$. The hospital managers should be sensitive to differences in their manufacture, acquisition, storage and disposal process. Criterions' observation will subsidize the best choice with the lowest cost to the institution, and greater security to the professionals who use them.

Regarding reusable aprons, in most hospitals, they are manufactured in the own institution, with the acquisition of raw materials, availability of human resources and equipment to manufacture them ${ }^{(7)}$. The process of reutilization of this kind of apron is held by the laundry service that is responsible for collecting the contaminated clothes in the care units, sorting, weighing, washing, repairing and distributing clean clothes ${ }^{(7)}$.

Thus, after use, reusable aprons are collected and subjected to the washing process in order to promote disinfection of fabric and decreasing the risk of nosocomial infection ${ }^{(8)}$. In case of identifying the impairment of protective function or the wear of the fibers, the reusable aprons are submitted to the disinfection process to reduce the microbial load, and when they do not present biological, chemical or radioactive risks to health or to the environment, are disposed as ordinary waste ${ }^{(9)}$.

Disposable aprons, on the other hand, are made of materials called nonwovens, which offer protection against the penetration of fluids. This type of apron has single use and are discarded as hazardous waste after use ${ }^{(10)}$. It is noteworthy that the expression hazardous waste refers to components with possible presence of biological agents, according to their concentration, can transmit infections. In public teaching hospitals, disposable aprons are acquired through bidding process ${ }^{(9)}$.

In recent years, the increased consumption of aprons contributed to a significant increase in costs related to them. Hospitals, concerned to restructure its financial management policy toward the scarcity of resources, seeking to combine costs on these products to the quality of care and safety for professionals who use $i^{(11)}$.

In public institutions, the process of cost management becomes even more complex given the need to combine a commitment to providing quality services to patients with limited resources ${ }^{(12)}$. Teaching hospitals, must maintain an adequate system of management of material resources that allow them to monitor rising prices, in addition to preserve the quality of acquired products and promote safety for users. Thus, the increase in reusable and disposable aprons consumption associated to the concern of hospital managers to reduce costs, ensure quality of care and safety for professionals justify the relevance of this study as an opportunity to analyze the direct costs spent with use of these products.

The present study will contribute to daily practice of hospitals to promote reflection on the management of reusable and disposable apron costs. The scarcity of research on the topic, especially in the field of nursing, reinforces the scientific contribution to the field of management of health services.

Given the above, this research analyzes the direct cost of reusable and disposable aprons in a public teaching hospital.

\section{METHOD}

This is a cross-sectional study with quantitative approach, focusing on the direct cost of reusable and
Costs of reusable and disposable aprons in a public teaching hospital

Pissinati PSC, Haddad MCL, Rossaneis MA, Gil RB, Belei RA 
disposable aprons in a public teaching hospital, located in the northern state of Paraná.

The institution studied provides $100 \%$ of its service capacity to the Unified Health System (SUS). Currently, the hospital has 316 beds, performs high-complexity care, outpatient clinic and hospitalization for all medical specialties.

This is a research of partial economic analysis, which can be used for comparing technologies, since it is centered only on the consequences or costs that they produce $^{(13)}$. This technique of partial economic analysis proved adequate to the purpose of the research, since it attempt to carry out a full assessment of costs, effectiveness and consequences, however we proposed to analyze only the direct cost of reusable and disposable aprons.

The study population consisted of secondary data. The source of data used were reports of the cost of services, laundry, and division of material and supplies of the institution for the year 2012.

To measure these variables, we used the system of direct costing, related to the production, ie quantifiable. With regard to the hospital area, basically composed by labor force, materials and equipment directly involved in the care process ${ }^{(14)}$.

The indirect cost of reusable and disposable aprons was not included in this study, since it comprises a portion of the total cost that cannot be attributed directly to the materials in analysis. Since they are obtained by apportionment criteria and involve expenditure from other products, services and units of the institution ${ }^{(15)}$, factors that could interfere with the analysis of the results.

Data collection was based on information from the cost reports of the institution. Thus, for reusable aprons, we calculated the cost of raw materials, cost of labor force to manufacture, the cost of a kilogram of washing and disposal process, while for disposable aprons were considered the unit cost of the acquisition and disposal, or even as hazardous waste.

Data were compiled and tabulated in Microsoft Office Excel and Word, version 2010, presented through graphs and tables.

This research is part of the project entitled Management of material resources in public and teaching hospitals institutions approved by the State University of Londrina Research Ethics Committee, as CAAE 03997212.8.0000.5231.

\section{RESULTS}

In the institution studied, manufacturing reusable aprons is held in the sewing service of the hospital, according to the semiannual schedule of activities. It involves the work of six workers to an average production of 600 aprons/year.

The direct cost of manufacturing reusable apron was obtained by summing the costs of labor and raw materials, and the calculation of the unit cost of direct labor was performed based on average wages of sewing service workers, corresponding to $\mathrm{R} \$ 899.22$, considering social charges, provisions for vacation and $13^{\text {th }}$ salary. These workers meet the workload of 40 hours, approximately 160 hours/month. Therefore, the unit cost of hours worked is equivalent to $\mathrm{R} \$ 5.62$.

It is noteworthy that for the production of 600 aprons is necessary six workers of the sewing sector, for a period of 32 hours. Thus, the institution spends on average $\mathrm{R} \$$ $1,079.04$ of labor for making this number of aprons, which corresponds to a unit cost of labor force of approximately $\mathrm{R} \$ 1.79$ /apron.

With respect to the raw material, it is necessary 4.6 meters of denim fabric, which cost for the institution $R \$$ $9.68 /$ meter, being spent $\mathrm{R} \$ 44.52$ /apron. Were used to two units handle, with a unit price of $R \$ 0.81$ and cost $\mathrm{R} \$ 1$ 1.62/apron. Still, were needed 100 meters of line, which costs $R \$ 0.08$ to every 10 meters, with a total value of $R \$ 0.80$ /apron. Thus, the average cost of raw material for each reusable apron produced corresponds to $\mathrm{R} \$ 46.94$ /apron. In Table 1, we present the direct cost of manufacturing one unit of reusable apron, approximately $\mathrm{R} \$ 48.73$.

Table 1 - Calculating the unit cost of manufacturing one unit of reusable apron at a public teaching hospital - Paraná, 2014

\begin{tabular}{lc}
\hline Cost Type & Cost in RS \\
\hline Direct cost & 1.79 \\
Cost of labor force & 46.94 \\
Raw material cost & $\mathbf{4 8 . 7 3}$ \\
Unit cost of manufacturing
\end{tabular}

In the studied hospital, reusable apron is classified as contaminated clothing and submitted to a specific wash cycle. The average costs $\mathrm{R} \$ \mathbf{5} .43$ per kilogram of washed cloth. Considering that the approximate weight of this equipment is $0.514 \mathrm{~kg}$, we obtain the unit cost of laundering equivalent to $\mathrm{R} \$ 2.79$ /apron.

Each reusable apron is subjected to a washing process, approximately 180 times/year. Thus, the average cost of wash from the first use until its disposal is $\mathrm{R} \$ 502.20$.

With the use or changes in the fabric structure, even after completion of repairs, reusable apron is disposal as common waste. The amount paid by the institution per kilogram of waste disposal is approximately $\mathrm{R} \$ 0.20$. Thus, this step generates an average unit cost of $R \$ 0.11$ /apron. Thus, the final cost of an reusable apron was calculated by the sum of the expenses of manufacturing, equivalent to $\mathrm{R} \$ 48.73$, total of $\mathrm{R} \$ 502.20$, spent on average with 180 
wash cycles and the unit cost of disposal of $\mathrm{R} \$ 0.11$, generating a unitary final cost of $R \$ 551.04$ /apron.

Then, we calculated the cost of each use of the reusable apron, performed by dividing the final cost of the unit, $R \$ 551.04$ by the average number of times the equipment is used, 180 times, which generates a using cost of $\mathrm{R} \$ 3.06 / a p r o n$.

Regarding disposable aprons, we calculated as a direct cost expenditure on purchasing this equipment, added the amount of disposal. Thus, disposable aprons, manufactured of a material called nonwoven were acquired through a bidding process, in electronic trading mode, and showed unit cost of approximately $\mathrm{R} \$ 0.84$ /apron. When purchased, these aprons are ready to use, single use, and, after the end of each procedure, not being subjected to the washing process are disposed of as hazardous waste.

The average cost for the disposal of a kilogram of hazardous waste is $\mathrm{R} \$ 2.45$. Considering that each disposable apron has approximate weight of $0.042 \mathrm{~kg}$, they spent on average R\$ 0.10/apron. Thus, the final cost of a disposable apron was obtained by the sum of the unit purchase price of this equipment, which corresponds to $\mathrm{R} \$ 0.84$ /apron, and the cost of the disposal process, $\mathrm{R} \$ 0.10$ /apron resulting in a total cost of usage of $\mathrm{R} \$ 0.94 /$ apron.

Therefore, we compared the direct cost of reusable and disposable aprons, as shown in Table 2.

The reusable apron showed higher using cost compared to disposable apron. It is noteworthy that the entire purchase process to the final disposal was considered for both equipment.

Table 2 - Comparison of unit cost of reusable fabric and disposable aprons in a public teaching hospital - Paraná, 2014

\begin{tabular}{lc}
\hline Cost calculation & Cost in R\$ \\
\hline Reusable apron & \\
Unit cost of manufacturing & 48.73 \\
Unit cost of washing* & 502.20 \\
Unit cost of disposal & 0.11 \\
Average cost of use & 3.06 \\
Disposable apron & \\
Unit cost of the apron & 0.84 \\
Unit cost of disposal & 0.10 \\
Average cost of use & 0.94 \\
\hline${ }^{*}$
\end{tabular}

${ }^{*}$ Considering 180 washes per apron.

Source: Annual Report of the Division of Hospital Cost (SCH), 2012.

\section{DISCUSSION}

We found in our study that the direct cost of a disposable apron was $\mathrm{R} \$ 0.94$, while the reusable apron cost $\mathrm{R} \$$ 3.06/unit in a public teaching hospital. Thus, there was a saving of $R \$ 2.12$ for the use of disposable aprons, as compared to reusable.
The steps of manufacturing and washing reusable aprons contributed to the increase of its direct cost, which reinforces the need for management assessment to the costs generated in laundry and sewing, given the volume and variety of clothes processed daily: sheets, drapes, towels, aprons, etc. ${ }^{(16)}$.

Apron should be able to protect the worker against potential hazard, such as contamination by multiresistant microorganisms ${ }^{(3)}$. By adopting reusable aprons is necessary that the institution uses an adequate washing process that reduces microbial levels and, consequently, the risk of transmitting nosocomial infections.

Regarding reuse, apron manufactured of denim fabric was reused, on average, 180 times and after this period, were identified wear on its structure, being necessary the disposal of the equipment. This happens due to multiple washings; fibers of the fabric are altered and show signs of wear reducing the capacity as microbial barrier. However, so far there is no determination of the maximum frequency of reusable equipment ${ }^{(17)}$.

As in the hospital where the study was conducted, many health institutions do not have a process for monitoring the shelf life of reusable products, using them until visual evidence of lack of integrity, which compromises the safety in its use ${ }^{(18)}$. Moreover, the manufacturing and cleaning of hospital products require the availability of labor force and time, factors that prolong this process. The difficulty of monitoring these steps can result in lower quality and safety of reusable aprons when compared to disposables.

Regarding disposable aprons, hospital acquired through electronic trading. This type of bidding is for the procurement of common goods and services in public institutions. This process is performed through of an electronic system in which the pricing dispute between bidders, individuals or companies to supply products at lowest price, meeting the description in the published notice ${ }^{(19)}$.

Because it is a public teaching hospital, with greater number of professionals, professors and students, there is high consumption of disposable aprons. Thus, it appears that the number of aprons acquired provides price competitiveness among suppliers that, in general, they offer the product at a cost below that obtained in other sales terms.

Regarding apron weight, disposable apron weight on average $0.042 \mathrm{~kg}$, while the reusable aprons weight approximately $0.514 \mathrm{~kg}$. Given this difference, it should be noted the use of aprons and verify if they hinder the performance of procedures or cause discomfort to workers. Such analysis is relevant because these variables may contribute to non-adherence to the use of personal protective equipment ${ }^{(20)}$.
Costs of reusable and disposable aprons in a public teaching hospital

Pissinati PSC, Haddad MCL, Rossaneis MA, Gil RB, Belei RA 
With regard to the cost of disposal, there was no significant difference between the two types of aprons, being the unitary cost of disposal of the reusable apron on average $\mathrm{R} \$$ 0.11/apron, and disposable apron $\mathrm{R} \$ \mathbf{0 . 1 0}$ / apron. Although the disposable apron be disposed as hazardous waste, which has a higher cost per kilogram of disposal, the low weight of this equipment makes it comparable to cost of disposal of reusable apron, classified as common waste.

It is noteworthy also that the reusable aprons are disposed as regular waste, while disposable aprons are segregated as contaminated waste. Therefore, these aprons belong to different waste groups of health services, with distinct lead to environmental impacts, which comprise any alteration of the physical, chemical and biological properties of the environment resulting from potential human activities. It comprises aspects related to safety, health, welfare of the population and the quality of environmental resources ${ }^{(21)}$.

It is noteworthy that the common waste do not present biological, chemical or radiological risks to health or environmental risks and thus are equivalent to household waste. Moreover, they can be subjected to recycling, reuse and recovery process, provided the standards of hygiene and decontamination ${ }^{(22)}$.

On the other hand, contaminated waste, also known as infectious, characterized by the possible presence of biological agents, due to the increased virulence capacity, can present a risk of infection. They must also be subjected to a treatment process that promotes the reduction of microbial load before being allocated to the final destination, and should not be reused or recycled ${ }^{(22)}$. Given these characteristics, the absence of waste pretreatment of health services can contribute to the proliferation of resistant bacteria to hospital and community antimicrobials. Still, residents from communities near the landfill and professionals working in these communities may be exposed to the risks of transmission of infectious diseases associated with these microorganisms ${ }^{(23)}$.

It is responsibility of managers to measure the volume of contaminated waste produced by segregation of disposable aprons, monitor treatment and the final destination of these products. Furthermore, it is necessary to develop strategies for reducing the risk of environmental impacts resulting from this type of disposal.

As regards the reusable aprons, although it is recognized that this practice may present a risk of failures in the reprocessing steps $^{(24)}$, there is a tendency to choose for these equipment in institutions. Therefore, managers have a culture of reusable aprons as an alternative of lower cost and greater safety to the work process.

By the differences between disposable and reusable aprons demonstrated in the present study, it is for hospital managers to conduct a careful assessment of the advantages and disadvantages of each product. This analysis should be based on financial, operational, safety and occupational health, and quality of aprons used.

We emphasize that the responsibility for determining which equipment and services to be used in the care process is the health care team. Thus, knowledge of cost management process of the institution by professionals is essential to the effectiveness of the costing system. The multidisciplinary participation will allow the results to be analyzed not only from the economic point of view, but they also promote improvements in the quality of public health services ${ }^{(12)}$.

\section{CONCLUSION}

We identified lower average cost of using disposable apron when compared to reusable apron. The unit cost of reusable apron was $R \$ 3.06 / a p r o n$, and the steps of manufacturing and washing mainly responsible for this increase in cost. In contrast, the disposable apron showed lower unit cost approximately $\mathrm{R} \$ 0.94 / a p r o n$.

This difference can be attributed to the purchase modality used for the acquisition of disposable apron, because bidding allow purchasing products at a lower price since they meet the criteria of the notice of electronic trading. Furthermore, the lack of spending on labor force, raw material for manufacturing and reprocessing of these aprons also contribute to financial advantage over reusable aprons.

The results demonstrate the importance of investing in analyzes of the cost of personal protective apron, mainly due to differences from the process of manufacturing to disposal. It is noteworthy that the choice of apron used in the institution should not be restricted to the financial aspects, as the costs it generates.

It is up to the manager to implement strategies to assess the safety of this equipment while microbial barrier, the wear resulted from reuse, and the occurrence of commitments to worker health due to the weight of the reusable apron. It also becomes necessary to overcome a culture of reuse of this material in various health institutions, considering that this practice should ensure safety to professionals and patients involved in the care.

We highlight the analysis of direct cost of reusable and disposable aprons, which allow us to evaluate the financial impact of such equipment in the operation of hospital services. In addition, the results presented here are tools for hospital managers properly allocating resources of the institution.

The development of research on health costs, particularly in nursing, is still limited. This reinforces the relevance of the development of the present study. Therefore, it is expected that the results found contribute to improve the cost management process and material resources in hospitals. 


\section{REFERENCES}

1. Espindola MCG, Fontana RT. Riscos ocupacionais e mecanismos de autocuidado do trabalhador de um centro de material e esterilização. Rev Gaúcha de Enferm [Internet]. 2012 [citado 2014 jul. 17];33(1):116-23. Disponível em: http://www.scielo. br/pdf/rgenf/v33n1/a16v33n1.pdf

2. Frota OP, Ferreira AM, Loureiro MDL, Cheade MFM, Reis MG. O uso de equipamento de proteção individual por profissionais de enfermagem na aspiração endotraqueal. Rev Enferm UERJ [Internet]. 2012 [citado 2014 jul. 17];20(n.esp): 625-30. Disponível em: http://www.facenf.uerj.br/v20nesp1/ v20e1a13.pdf

3. Royal College of Physicians of Ireland. Guidelines for the Prevention and Control of Multi-drug resistant organisms (MDRO) excluding MRSA in the healthcare setting. Dublin 2, Ireland; 2012.

4. Brasil. Ministério do Trabalho e Emprego. Portaria MTE/SIT n. 194, de 7 de dezembro de 2010. Altera a Norma Regulamentadora n. 6. Equipamento de proteção individual [Internet]. Brasília; 2010 [citado 2013 jul. 19]. Disponível em: http:// www.cmqv.org/website/artigo.asp?cod $=1461$ \&idi $=1 \&$ moe $=2$ $12 \&$ id $=17192$

5. Carvalho RH, Gontijo Filho PP. Epidemiologically relevant antimicrobial resistance phenotypes in pathogens isolated from critically ill patients in a Brazilian Universitary Hospital. Braz J Microbiol. 2008;39(4):623-30.

6. Gruendemann BJ. Taking cover: single-use vs. reusable gowns and drapes. Infect Control Today. 2002;6(1):32-4.

7. Brasil. Ministério da Saúde; Agência Nacional de Vigilância Sanitária. Processamento de Roupas de Serviços de Saúde [Internet]. Brasília; 2009 [citado 2014 jun. 17]. Disponível em: http://www.anvisa.gov.br/servicosaude/manuais/processamento_roupas.pdf

8. Dias LG, Santos GRN, Borges JRL, Costa LMM, Souza IC, Passos XS, et al. Processamento de artigos têxteis em lavanderia hospitalar: um relato de experiência. Nursing (São Paulo). 2012;15(171):434-7.

9. Brasil. Ministério da Saúde; Agência Nacional de Vigilância Sanitária. Manual de Gerenciamento de Resíduos de Serviços de Saúde [Internet]. Brasília; 2006 [citado 2014 jun. 17]. Disponível em: http://www.anvisa.gov.br/servicosaude/manuais/manual_gerenciamento_residuos.pdf

10. Rutala WA, Weber DJ. A review of single-use and reusable gowns and drapes in health care. Infect Control Hosp Epidemiol. 2001;22(4):248-57.
11. Oliveira WT, Rodrigues AVD, Haddad MCL, Vannuchi MTO, Taldivo MA. Conceptions of nurses from a public university hospital regarding the cost management report. Rev Esc Enferm USP [Internet]. 2012 [cited 2014 June17];46(5): 1184-91. Available from: http://www.scielo.br/pdf/reeusp/ v46n5/en_21.pdf

12. Dallora MELV, Forster AC. A importância da gestão de custos em hospitais de ensino: considerações teóricas. Medicina (Ribeirão Preto). 2008;41(2):135-42.

13. Brasil. Ministério da Saúde; Secretaria da Ciência, Tecnologias e Insumos Estratégicos, Departamento de Ciência e Tecnologia. Diretrizes metodológicas: estudos de avaliação econômica em saúde [Internet]. Brasília; 2009 [citado 2014 jun. 17]. Disponível em: http://bvsms.saude.gov.br/bvs/publicacoes/ avaliacao_economica_tecnologias_saude_2009.pdf

14. Castilho V, Fugulin FMT, Gaidzinsk RR. Gerenciamento de custos nos serviços de enfermagem. In: Kurcgant P. Gerenciamento de enfermagem. Rio de Janeiro: Guanabara Koogan; 2010. p. 171-83.

15. Brasil. Ministério da Saúde; Secretaria da Ciência, Tecnologias e Insumos Estratégicos, Departamento de Ciência e Tecnologia. Glossário temático: economia da saúde [Internet]. Brasília; 2009 [citado 2014 jun. 17]. Disponível em: http:// bvsms.saude.gov.br/bvs/publicacoes/glossario_ecos2.pdf

16. Cunha AMCA, Campos CE, Rifarachi HHC. Aplicabilidade da metodologia Lean em uma lavanderia hospitalar. Mundo Saúde. 2011;35(5):311-8.

17. Burgatti BJ, Lacerda RA. Systematic review of surgical gowns in the control of contamination/surgical site infection Rev Esc Enferm USP. 2009;43(1):237-44.

18. Freitas LR, Tipple AFV, Felipe DP. Embalagem de tecido de algodão: análise do uso em hospitais de médio e grande porte. Rev Eletr Enferm [Internet]. 2012 [citado 2014 jun. 17];14(4):811-20. Disponível em: https://www.revistas.ufg. br/index.php/fen/article/view/16612/13345

19. Brasil. Decreto 5.450/2005, de 31 de maio de 2005. Regulamenta o pregão, na forma eletrônica, para a aquisição de bens e serviços comuns, e dá outras providências [Internet]. Brasília; 2005 [citado 2014 jun.17]. Disponível em: http:// www.planalto.gov.br/ccivil_03/_ato2004-2006/2005/decreto/d5450.htm

20. Souza ELV, Nascimento JC, Caetano JA, Ribeiro RCV. Uso dos equipamentos de proteção individual em Unidade de Terapia Intensiva. Rev Enferm Referência [Internet]. 2011 [citado 2014 jun. 17]; serllI(4):125-33. Disponível em: http://www. scielo.gpeari.mctes.pt/pdf/ref/vserllIn4/serllIn4a13.pdf 
21. Brasil. Conselho Nacional de Meio Ambiente. Resolução no 001, de 23 de janeiro de 1986. Estabelece as definições, as responsabilidades, os critérios básicos e as diretrizes gerais para uso e implementação da avaliação de impacto ambiental como um dos instrumentos da política nacional do meio ambiente [Internet]. Brasília; 1986 [citado 2014 jun. 17]. Disponível em: http://www.mma.gov.br/port/conama/res/ res86/res0186.html

22. Brasil. Conselho Nacional de Meio Ambiente. Resolução $n$. 358, de 29 de abril de 2005. Dispõe sobre o tratamento e a disposição final dos resíduos dos serviços de saúde e dá outras providências [Internet]. Brasília; 2005 [citado 2014 jun. 17]. Disponível em: http://www.mma.gov.br/port/conama/ legiabre.cfm?codlegi $=462$
23. Nascimento TC, Januzzi WA, Leonel M, Silva VL, Diniz CG. Ocorrência de bactérias clinicamente relevantes nos resíduos de serviços de saúde em um aterro sanitário brasileiro e perfil de susceptibilidade a antimicrobianos. Rev Soc Bras Med Trop. 2009;42(4):415-9.

24. Costa EAM, Costa EA. Risco e segurança sanitária: análise do reprocessamento de produtos médicos em hospitais de Salvador, BA. Rev Saúde Pública [Internet]. 2012 [citado 2014 jun. 17];46(5):800-7. Disponível em: http://www.scielo.br/ $\mathrm{pdf} / \mathrm{rsp} / \mathrm{v} 46 \mathrm{n} 5 / 06 . \mathrm{pdf}$ 